\title{
Monitoring levels of deoxynivalenol in wheat flour of Brazilian varieties
}

\author{
Cristiano L. Silva ${ }^{1}$, Giovani Benin ${ }^{1 *}$, André C. Rosa ${ }^{2}$, Eduardo Beche ${ }^{1}$, Elesandro Bornhofen ${ }^{1}$, \\ and Márcio A. Capelin ${ }^{1}$
}

Deoxynivalenol (DON) is a mycotoxin produced by Fusarium graminearum and its intake represents a severe risk to human and animal health. The objective of this study was to evaluate levels of DON in wheat (Triticum aestivum L.) flour from two representative locations of south Brazil. Experiments were carried out in Pato Branco (Paraná) and Coxilha (Rio Grande do Sul) in a randomized complete block design with three replicates. Levels of DON were measured by highperformance liquid chromatography coupled with mass spectrometry (HPLC-MS/MS). This mycotoxin was detected in $97 \%$ of samples, ranging from 200 to $4140 \mu \mathrm{g} \mathrm{kg}^{-1}$. Only $17 \%$ of samples presented DON beyond of the maximum allowed by the Brazilian Health Surveillance Agency up to the year 2012; even though, Fusarium head blight (FHB) epidemics were slight low in the growing season that the study was performed. According to our knowledge, this is the first report showing genetic variability of Brazilian cultivars to DON contamination and some genotypes have potential to be exploited as a source of low accumulation of this toxin.

Key words: Fusarium head blight, micotoxin, Triticum aestivum, wheat flour.

\section{INTRODUCTION}

Annually it is produced around 5 million tons of wheat (Triticum aestivum L.) in Brazil and the states of Paraná and Rio Grande do Sul are the leading producers, representing more than $90 \%$ of national production (CONAB, 2013). The weather conditions in this region are characterized by high humidity and heavy rainfall during the wheat season which benefits development of several pathogens, especially Fusarium graminearum (teleomorph Gibberella zeae) (West et al., 2012). This fungus causes a disease known as Fusarium head blight (FHB) or scab.

Besides causing losses up to $25 \%$ in the grain yield (Casa et al., 2004), this pathogen also produces mycotoxins that contaminate wheat grains and flour, being harmful to human and animal health (Mishra et al., 2013). Among these mycotoxins, the deoxynivalenol (DON) point out as one of the most important toxin (CaloriDomingues et al., 2007). DON belongs to trichothecene group of toxins, soluble in water, polar solvents, stable up to temperature of $120{ }^{\circ} \mathrm{C}$, and is not decomposed at slightly acidic conditions (Hallen-Adams et al., 2011).

${ }^{1}$ Universidade Tecnológica Federal do Paraná, 85503-390, Pato Branco, Paraná, Brasil. "Corresponding author (benin@utfpr.edu.br). ${ }^{2}$ Biotrigo Genética, 99050-380, Passo Fundo, Rio Grande do Sul, Brasil.

Received: 24 April 2014.

Accepted: 4 December 2014.

doi:10.4067/S0718-583920150001200007
Consumption of food contaminated with DON can cause many adverse symptoms such as feed refusal, reduced weight gain, diarrhea, and vomiting (Moazami and Jinap, 2009), neurotoxic disturbs (Ndossi et al., 2012), and even carcinogenic effects (Shephard, 2011). This toxin is most prevalent in the exterior parts of the grains, showing higher levels in the bran than wheat grain and flour (Samar et al., 2003) due to the predominance of $F$. graminearum in the superficial tissues of grains such as the pericarp and aleurone. Hence, the milling process decreases the levels of DON in the wheat flour (Santos et al., 2013; Cui et al., 2013).

The most effective way to minimize DON levels is using varieties resistant to FHB and preventively applying fungicides to control $F$. graminearum. Likewise, the levels of this toxin tend to differ among wheat varieties and according to Miller and Arnison (1986), a lower DON level occurs for three main reasons: (1) small toxin production by the fungus, (2) DON degradation by plant enzymes during grain development, (3) DON accumulation in other parts of the spikes instead of grains. Furthermore, the severity of FHB is positively associated (0.78) with the presence of 'pinkish grains' (Fusariumdamaged kernels) (Bonin and Kolb, 2009), which also are strongly correlated with the occurrence of DON, being a trait easy to evaluate.

Several countries already have laws regulating maximum levels of DON in grains and wheat flour (Codex Alimentarius Commission, 2012) (Table 1). For instance, Cui et al. (2013) verified that $89.3 \%$ of flour 
Table 1. Allowed limits of deoxynivalenol (DON) in wheat and wheat-based products by country.

\begin{tabular}{|c|c|c|}
\hline Countries & Food products & DON limits $\left(\mu \mathrm{g} \mathrm{kg}^{-1}\right)$ \\
\hline \multirow[t]{2}{*}{ Brazil (a) } & Wheat grain, whole-wheat flour & $2000 / 1500 / 1000$ \\
\hline & Wheat flour, pasta, crackers, cookies and bakery products & $1750 / 1250 / 750$ \\
\hline \multirow{2}{*}{ Canada $^{(b)}$} & Uncleaned soft wheat for use in non-staple foods & 2000 \\
\hline & Uncleaned soft wheat for use in baby foods. & 1000 \\
\hline $\mathrm{USA}^{(\mathrm{b})}$ & Wheat products in general & 1000 (provisional) \\
\hline Russia $^{(b)}$ & Wheat and wheat cereal, wheat flour; pasta products; bread; bakery products & 700 \\
\hline China $^{(b)}$ & Wheat, breakfast cereals, wheat flour & 1000 \\
\hline India $^{(\mathrm{b})}$ & Wheat and wheat flour & 1000 \\
\hline $\operatorname{Japan}^{(\mathrm{b})}$ & Wheat and wheat flour & 1100 (provisional) \\
\hline \multirow[t]{3}{*}{ Codex Members ${ }^{(b)}$} & Wheat grain and its unprocessed food products & 2000 \\
\hline & Wheat flour, pasta, and bakery products & 1000 \\
\hline & Food products for infants and young children & 500 \\
\hline
\end{tabular}

(a) Brazilian limits of DON established by ANVISA (2011) respectively for the year 2012, 2014, and 2016.

(b)Limits of DON according to the Codex Alimentarius Commission (2012). Currently 185 countries are members of this commission.

samples were contaminated with DON in China, and $70 \%$ of them presented DON values above the allowed limit. Similar results were also reported in India (Mishra et al., 2013), Malaysia (Moazami and Jinap, 2009), Germany (Maul et al., 2012), England (West et al., 2012), and Italy (Blandino et al., 2012). Therefore, these studies pointed out that the occurrence of DON above the limits tolerated in wheat is a common issue worldwide.

Primarily, Calori-Domingues et al. (2007) reported values of DON in Brazilian wheat 3.7 fold higher than in imported wheat, showing concern about this toxin levels. However, a few studies have been investigating the natural occurrence of this toxin and its hazardous effects on human and animal health in Brazil. Then, the National Agency for Sanitary Surveillance (ANVISA) published the Resolution - RDC nr 7 at 18 February 2011 limiting the DON levels on wheat. According to this guideline the limits in whole wheat grains, bran, and flour are 2000, 1500 , and $1000 \mu \mathrm{g} \mathrm{kg}^{-1}$, respectively, for the years 2012 , 2014, and 2016; while for manufactured products such as wheat flour, pasta, crackers, and cookies the limits are 1750,1250 , and $750 \mu \mathrm{g} \mathrm{kg}^{-1}$ for the same years (Table 1). The limits will be gradually decreased over the years in order to allow producers and industries to adapt to the new requirements without causing wheat shortage.

Thus, the objective of this study was to evaluate the performance of Brazilian wheat cultivars recently released, for natural occurrence of deoxynivalenol toxin in two locations in the states of Parana and Rio Grande do Sul.

\section{MATERIALS AND METHODS}

In the 2011 growing season, experiments were carried out in two representative locations in southern Brazil: Pato Branco (26 $09^{\prime}$ S, 52 $42^{\prime} \mathrm{W}$; $760 \mathrm{~m}$ a.s.1.) and Coxilha $\left(28^{\circ} 13^{\prime} \mathrm{S}, 52^{\circ} 22^{\prime} \mathrm{W}\right.$; $690 \mathrm{~m}$ a.s.1.), which are located in the states of Parana and Rio Grande do Sul, respectively. The experiment was sown at the Experimental Station of the Federal Technological University of Paraná (UTFPR) in Pato Branco which has a Haplorthox soil. In Coxilha the experiment was conducted at the experimental area of
Biotrigo Genética, where the soil is classified as Typic red Hapludox. Data of the cumulative monthly rainfall and variation of temperatures during the experiment period are shown in Figure 1.

In each experiment, cultivars were sown in a randomized complete block design with three replicates, using a precision seed drill. The 18 wheat cultivars evaluated in this study (Table 2) represent more than $70 \%$ of wheat varieties grown in southern Brazil in the 2011 .

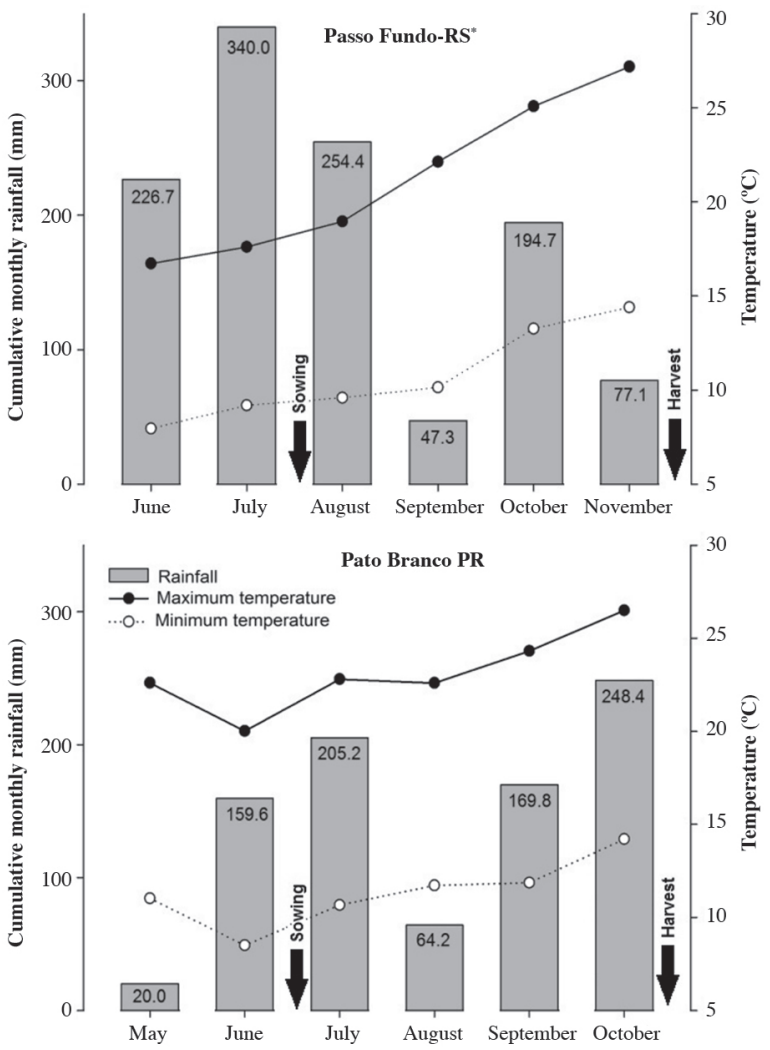

Source: Agricultural Institute of Paraná (Instituto Agronômico do Paraná IAPAR), Meteorological System of Parana (Sistema Meteorológico do Paraná, Simepar) and Embrapa Trigo.

Figure 1. Cumulative monthly rainfall and variation of temperatures for the trial period in the locations of Coxilha (Rio Grande do Sul) and Pato Branco (Paraná). *Passo Fundo-RS is the weather station nearest Coxilha-RS. 
Table 2. Name, owners, year of release and pedigrees of the cultivars used in the study.

\begin{tabular}{|c|c|c|c|}
\hline Cultivars & Owner & Year of release & Pedigree \\
\hline Quartzo & OR/Biotrigo Genética & 2008 & Ônix/Avante \\
\hline Mirante & OR/Biotrigo Genética & 2009 & Ônix/Taurum/Ônix \\
\hline Marfim & OR/Biotrigo Genética & 2007 & ORL $94101 / 2 *$ ORL 95688 \\
\hline TBIO Pioneiro & Biotrigo Genética & 2010 & Cronox/Vaqueano \\
\hline TBIO Iguaçu & Biotrigo Genética & 2011 & Quartzo/Safira \\
\hline TBIO Itaipu & Biotrigo Genética & 2010 & Quartzo/Safira \\
\hline BRS Guamirim & Embrapa Trigo & 2006 & EMB 27/BUCK MANDUI//PF 93159 \\
\hline BRS Tangará & Embrapa Trigo & 2007 & BR 23*2/PF 940382 \\
\hline BRS 220 & Embrapa Trigo & 2003 & EMBRAPA16/TB108 \\
\hline F. Raízes & CCGL Fundacep & 2007 & EMB27/CEP 4/3/BUC"S"/FCT"S"//PF 85229 \\
\hline F. Cristalino & CCGL Fundacep & 2006 & BR 35/CEP 9291/4/BR 32/3/CNO 79/PF 70354/MUS“S” \\
\hline F. Horizonte & CCGL Fundacep & 2009 & BRS 119/CEP 97184 \\
\hline CD 122 & Coodetec & 2010 & IPR 85/WT 96168 \\
\hline CD 117 & Coodetec & 2007 & PF 87373/OC 938 \\
\hline CD 150 & Coodetec & 2009 & CD 104/CD108 \\
\hline IPR Catuara TM & IAPAR & 2006 & IA 976/LD 972 \\
\hline IPR 130 & IAPAR & 2008 & Rayon//Vee\#6/Trap\#1 \\
\hline IPR 144 & IAPAR & 2009 & SERI*3/BUC/5/BOW/3/CAR \\
\hline
\end{tabular}

Each plot was formed by nine rows of $4.0 \mathrm{~m}$ in length, spaced $0.2 \mathrm{~m}$ apart, with a seeding density of 350 seeds $\mathrm{m}^{-2}$. The sowing dates were 20 June and 28 July 2011 in Pato Branco and Coxilha locations, respectively.

Base fertilization consisted of applying $300 \mathrm{~kg} \mathrm{ha}^{-1}$ of NPK of commercial formulation 8-20-20 (NPK). At the beginning of tillering (Z22 stage, Zadoks et al., 1974) the fertilization was supplemented with $50 \mathrm{~kg} \mathrm{~N}^{-1}$ in urea form $(45 \% \mathrm{~N})$. Weed control was performed $30 \mathrm{~d}$ after emergence of the wheat applying iodosulfuron methyl (Hussar, Bayer CropScience, Hawthorn East, Victoria, Australia) at a dose of $90 \mathrm{~g} \mathrm{ha}^{-1}$ along with 500 $\mathrm{mL} \mathrm{ha}^{-1}$ of its adjuvant (Hoefix, Bayer CropScience). Insects, especially aphids, were controlled spraying the insecticide imidacloprid (Imidacloprid $350 \mathrm{SC}$, Imidacloprid 350 SC, Rotam Agrochemical, Hong Kong, China) at a dose of $100 \mathrm{~mL} \mathrm{ha} \mathrm{a}^{-1}$ in the initial stage of the crop development. Subsequently, the diseases were controlled with 3 applications of fungicide using 600 $\mathrm{mL} \mathrm{ha}{ }^{-1}$ trifloxystrobin+tebuconazole (Nativo, Bayer CropScience) along with $500 \mathrm{~mL}$ of mineral oil (Nimbus, Syngenta). The first application was right before anthesis (Z48 stage) and the following treatments were performed during the grain filling. All these crop managements were made according to the Brazilian technical recommendations of wheat.

The experiments were harvested with a plot combine in the end of October and November, respectively in Pato Branco and Coxilha (Figure 1). Grain samples ( $100 \mathrm{~g}$ ) were previously cleaned and uniformed at $13 \%$ moisture and then milled on analytical mill (model IKA A11 BS32) at Seed Laboratory of UTFPR. Then, samples were standardized using mesh sieve $(250 \mu \mathrm{m})$. After that, flour samples were sent to the Analytical Laboratory Mycotoxicologic (LAMIC) in the Federal University of Santa Maria, Santa Maria, Rio Grande do Sul. Subsequently, the levels of DON were analyzed through the method of high performance liquid chromatography coupled with mass spectrometry (HPLC-MS/MS). This chromatograph has a high efficiency LC-20AT pump system, array detector SPD-M20A diode model, auto injector SIL-20AHT, and CBM-20A system controller connected to computer containing LC Solution software (Shimadzu, Kyoto, Japan).

Data were subjected to statistical ANOVA, considering fixed effects to genotypes and random to environment. All traits significant by F test were grouped by Scott and Knott test, at 5\% significance level ( $\mathrm{p} \leq 0.05)$. This test aims to split the treatments in different groups, minimizing variation within and maximizing the variation between groups. Thus, the results can be easily interpreted, due to the absence of ambiguity and result in greater objectivity and clarity, mostly when comparing several treatments (Borges and Ferreira, 2003).

Additionally, it was estimated the Pearson's correlation between the environments. The selective accuracy (SA) for genotypes was also calculated, using the following expression:

$$
S A=\sqrt{1-\frac{1}{M S_{G / M S_{E}}}}
$$

where MSG is mean square of genotypes and MSE is mean square error. The broad-sense heritability was calculated by dividing the genotypic variance by the phenotypic variance: $H^{2}=\sigma^{2}{ }_{G} / \sigma_{P}^{2}$. These analyses were performed through Genes software (Cruz, 2013) and the graphs of frequency distribution, with classes and boxplots were built using the software Statistica (StatSoft, Tulsa, Oklahoma, USA) and Sigmaplot 11.0 (SYSTAT, San José California), to check the symmetry distribution of the studied data.

\section{RESULTS AND DISCUSSION}

Significant effects were identified $(p \leq 0.01)$ for environment, cultivars, and Cultivar $\times$ Environment interaction (Table 3), corroborating partially with results reported by Blandino et al. (2012), who observed environmental effects playing major role in the natural occurrence of DON. However, the estimates of genetic variance $\left(\sigma^{2}{ }_{G}\right)$ of DON in the current study were significant greater than the environmental variance $\left(\sigma^{2} \mathrm{E}\right)$ in both 
Table 3. ANOVA and genetic estimates of deoxynivalenol (DON) levels in samples of wheat flour of 18 representative cultivars planted in two locations of south Brazil.

\begin{tabular}{|c|c|c|c|c|c|c|}
\hline Sources of variation & Blocks/Env. & Cultivars & Environments & Cult. $\times$ Env & Error & SA \\
\hline Degrees of freedom & 4 & 17 & 1 & 17 & 68 & 0.98 \\
\hline Means squares & 242965 & $3945108^{* *}$ & $2422805^{* *}$ & $935653^{* * *}$ & 107357 & \\
\hline Locations & Mean & $\mathrm{CV}_{\%}$ & $\sigma^{2} \mathrm{E}$ & $\sigma^{2} \mathrm{G}$ & $H^{2}$ & $\begin{array}{l}\text { Accumulated } \\
\text { rainfall }\end{array}$ \\
\hline Pato Branco & 1058.2 & 21.34 & 16998 & 541541.3 & 0.91 & $790 \mathrm{~mm}$ \\
\hline Coxilha & 1357.8 & 29.95 & 55136.5 & 1013245 & 0.94 & $613 \mathrm{~mm}$ \\
\hline
\end{tabular}

*** Values significant at $1 \%$ level of probability error $(\mathrm{p} \leq 0.01)$ by $\mathrm{F}$ test; GLtotal 107 ; SA: selective accuracy; CV: coefficient of variation; $\sigma^{2} \mathrm{E}$ : environmental variance; $\sigma^{2}$ : genotypic variance, $H^{2}$ : broad sense heritability; accumulated rainfall refers to period between sowing and harvest.

locations showing that genotypic effects are predominant in this case. Although the coefficients of variation were slightly high, the selective accuracy (SA) to genotypes was 0.98 , demonstrating that the experiments presented high trial precision.

The average levels of DON found in flour samples from Coxilha $\left(1357.8 \mu \mathrm{g} \mathrm{kg}^{-1}\right)$ were significantly higher than the values of DON in Pato Branco $\left(1058.2 \mu \mathrm{g} \mathrm{kg}^{-1}\right)$, even though the accumulated rainfall during grain filling was roughly 3 -fold higher in Pato Branco (Figure 1). It suggests that heavy rainfall by itself may not a reasonable parameter to predict DON levels in wheat. Perhaps, a combination of constant rain distribution after anthesis (high relative humidity) along with slight low temperatures $\left(16-20{ }^{\circ} \mathrm{C}\right)$ seems to be more crucial to the epidemics. Although, the mean values of DON obtained in each location were lower than the limit established by ANVISA (2011) for the year $2012\left(1750 \mu \mathrm{g} \mathrm{kg}^{-1}\right)$, but still above the $1000 \mu \mathrm{g}$ $\mathrm{kg}^{-1}$ which will be required in 2016 .

According to SISALERT website (SISALERT, 2011), the 2011 growing season was characterized by low to medium risk of a FHB epidemic with severity ranging from $1.77 \%$ to $3.75 \%$ in Pato Branco, and $0 \%$ to $2.75 \%$ in Passo Fundo (Figure 2). SISALERT is a system created to predict FHB epidemics based on the interpolation of climatic indices from a network of weather stations in southern Brazil and generating risk maps of the disease occurrence. Thus, it allows farmers preventively spray their fields with fungicides, increasing the efficiency of the chemical control (Del Ponte et al., 2004). Despite the fact that three applications of fungicides were performed in the experiment, DON was detected in $97.23 \%$ of samples, ranging from 200 to $4140 \mu \mathrm{g} \mathrm{kg}^{-1}$ (Figure 3). It indicates that is hard to get totally rid of this toxin even when the severity of the disease is low (SISALERT, 2011) and fungicides applications are correctly done, suggesting that genetic resistance to FHB and DON accumulation play important role. Moreover, $44 \%$ of samples were categorized in the class with DON levels lower than 773 $\mu \mathrm{g} \mathrm{kg}^{-1}$, i.e. close to the limits established by ANVISA up to the year 2016. Elevated rainfall (613 and 790 $\mathrm{mm}$ ) during the whole crop cycle in both locations also contributed to the high contamination level (Figure 1), corroborating with the results of Stanković et al. (2012) who pointed out superior levels of DON occurred when heavier rainfall happened during flowering and heading stages.

Only $17 \%$ of samples had values of DON greater than $2120 \mu \mathrm{g} \mathrm{kg}^{-1}$ (Figure 3). These levels were above the limits established by ANVISA, classifying the flour as unsafe for human and animal consumption. It agrees with results previously obtained in the state of Paraná by Santos et al. (2013), who reported contamination of DON in $66.4 \%$ of the samples and $20 \%$ of it had DON values higher than the levels established by ANVISA. Likewise, Mishra et al. (2013) found $30 \%$ of DON contamination on wheat flour in India, where $7 \%$ of it exceeded the maximum limits established by the laws of that country's food security (Table 1).

The cv. BRS 220 showed the highest value of DON in Pato Branco-PR (2259 $\left.\mu \mathrm{g} \mathrm{kg}^{-1}\right)$, differing from the second homogeneous group formed by Scott Knott test ( $\mathrm{p}=0.05)$, which was formed by the cultivars IPR 144 (2056 $\left.\mu \mathrm{g} \mathrm{kg}^{-1}\right)$, IPR Catuara $\left(1798 \mu \mathrm{g} \mathrm{kg}^{-1}\right)$, and CD 122 $\left(1703 \mu \mathrm{g} \mathrm{kg}^{-1}\right)$. On the other hand, the highest levels of DON contamination in Coxilha-RS were detected in the genotypes BRS Tangará $\left(3923 \mu \mathrm{g} \mathrm{kg}^{-1}\right)$ followed by IPR Catuara (3133 $\left.\mu \mathrm{g} \mathrm{kg}^{-1}\right)$, IPR $144\left(2680 \mu \mathrm{g} \mathrm{kg}^{-1}\right)$, BRS $220\left(2250 \mu \mathrm{g} \mathrm{kg}^{-1}\right)$, and CD $150\left(1890 \mu \mathrm{g} \mathrm{kg}^{-1}\right)$ (Figure 4). Additionally, the DON data were significant correlated $(0.65)$ between the locations, indicating that the cultivars tend to present a similar behavior in both environmental conditions (Figure 4). The differences in DON accumulation among tested varieties could also be attributed to the presence of resistant parental lines in the pedigree and distinct breeding strategies adopted by breeding programs.

Some cultivars presented low levels of DON contamination in both locations (Figure 4). The best genotypes were: 'F. Raízes' (213-241 $\left.\mu \mathrm{g} \mathrm{kg}^{-1}\right)$, 'TBIO Iguaçu' (571-449 $\mu \mathrm{g} \mathrm{kg}^{-1}$ ), 'Marfim' (336-528 $\left.\mu \mathrm{g} \mathrm{kg}^{-1}\right)$, 'TBIO Pioneiro' (145-678 $\mu \mathrm{g} \mathrm{kg}^{-1}$ ), 'Quartzo' (548-636 $\left.\mu \mathrm{g} \mathrm{kg}^{-1}\right)$, and 'F. Cristalino' (643-712 $\left.\mu \mathrm{g} \mathrm{kg}^{-1}\right)$, respectively in Pato Branco and Coxilha. All these values are already lower than the limit established by ANVISA for the year 2016. These cultivars could have been selected under a condition of greater selection pressure for FHB, once they were released by breeding programs located in Rio Grande do Sul state where the occurrence of FHB is historically higher than other regions of Brazil. 

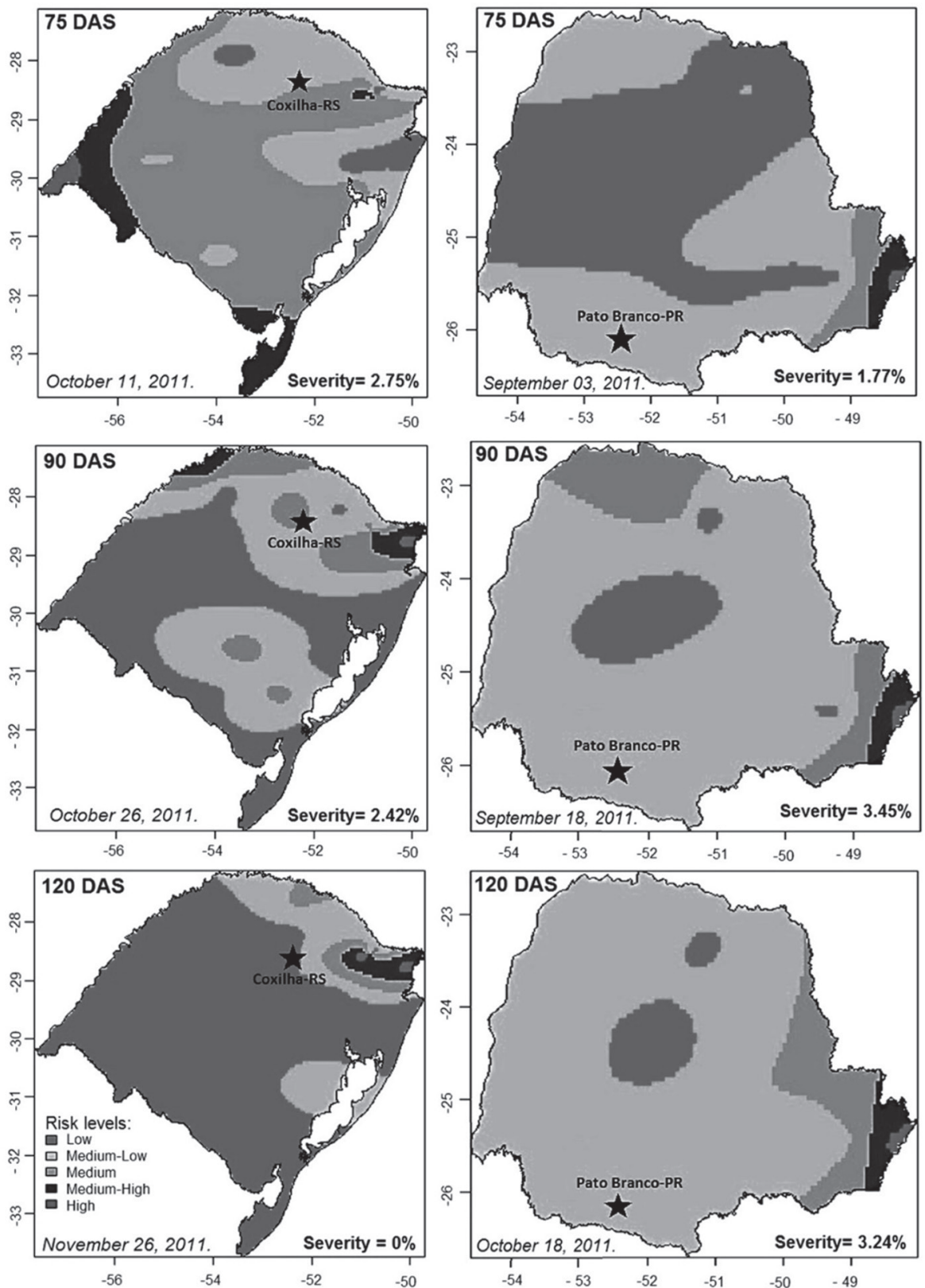

Figure 2. Risk map of occurrence of Fusarium head blight in the locations of Pato Branco (Paraná) and Coxilha (Rio Grande do Sul) after anthesis at 75,90, and $120 \mathrm{~d}$ after sowing (DAS) according to SISALERT predictive model.

Several authors suggest that increasing the selection pressure in early generations, through strategies such as irrigation and inoculation, facilitates the visual selection against Fusarium-damaged kernels (pinkish grains) which are highly associated with DON occurrence (Agostinelli et al., 2012). Likewise, the test trials in multienvironments and marker assisted selection also raise the odds of selecting genotypes more resistant to FHB and consequently with lower levels of DON (Rutkoski et al., 2012; Agostinelli et al., 2012). These approaches also could be used for screening the commercial cultivars that have been grown in Brazil, classifying them according to the FHB resistance as well indirectly ranking for DON accumulation.

Maintaining the levels of DON within allowed levels requires short and long-term strategies. The shortterm strategies consist of practices such as control of FHB through fungicides and techniques to increase its application efficiency (Del Ponte et al., 2012) and using predictive models (e.g. SISALERT). Likewise, monitoring methods during the harvest for instance using rapid tests (kits) in units receiving grains and elevators allow separating the wheat according to the levels of DON. Currently, several rapid test kits for quantification 


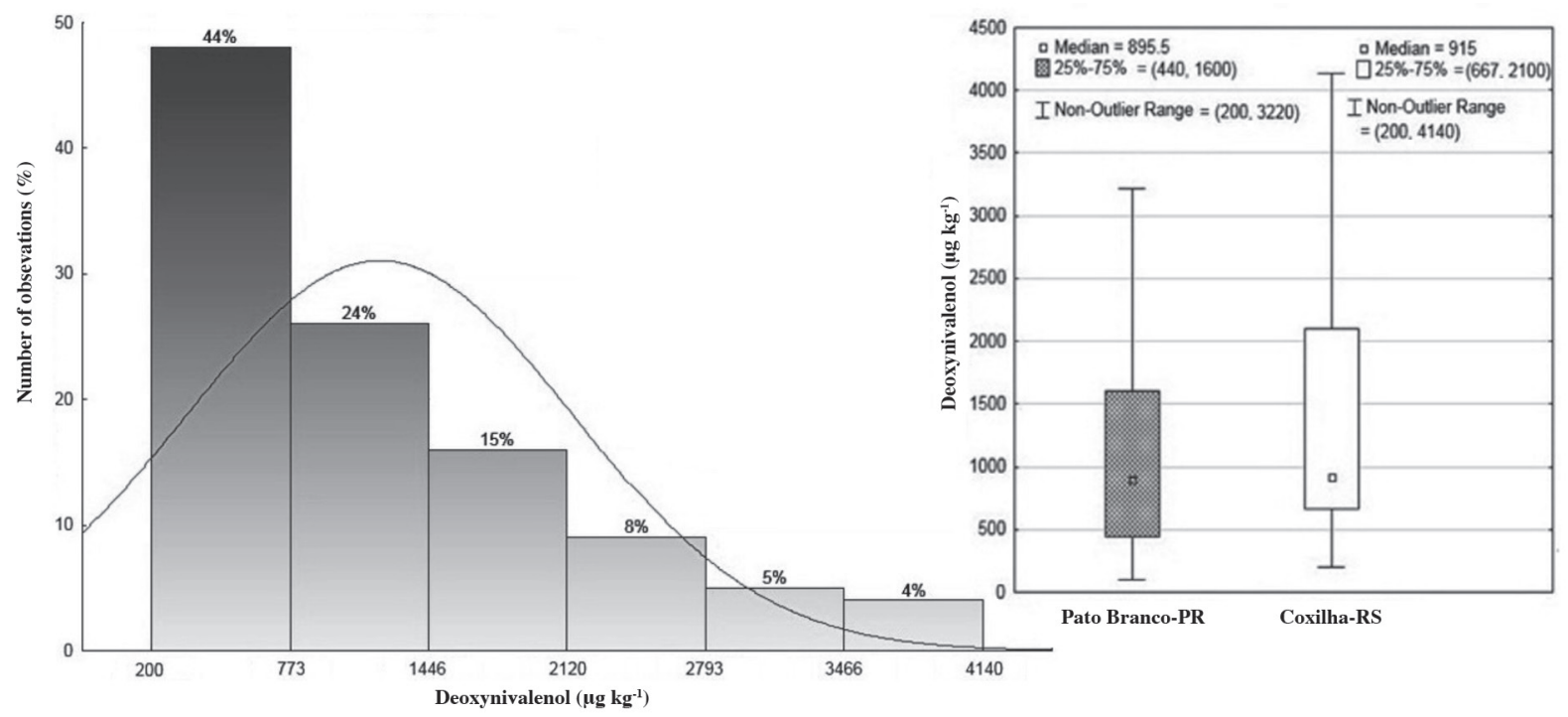

Figure 3. Frequency distribution and boxplot values of deoxynivalenol (DON) in samples of wheat flour of 18 cultivars grown in two representative locations of south Brazil, Pato Branco (Paraná) and Coxilha (Rio Grande do Sul).

of DON are available in the market, being reasonably cheap and faster than the traditional laboratory procedures. On the other hand, long-term strategies basically refer to breeding approaches, once takes around $10 \mathrm{yr}$ from cross until the release of a new cultivar. Thus, sources of FHB resistance and low DON accumulation should be used in crosses and backcrosses with the Brazilian varieties aiming to increase FHB resistance in order to attend these new market requirements. That would allow pyramiding distinct genes of resistance which can be facilitated through marker assisted selection techniques.

Although the overall levels of resistance to FHB are historically low, this study found variability among Brazilian cultivars to DON contamination, which is possibly due to different degrees of resistance to FHB among the tested genotypes. Nonetheless, the relationship between FHB resistance and DON accumulation needs to be investigated in depth on future studies. A few samples

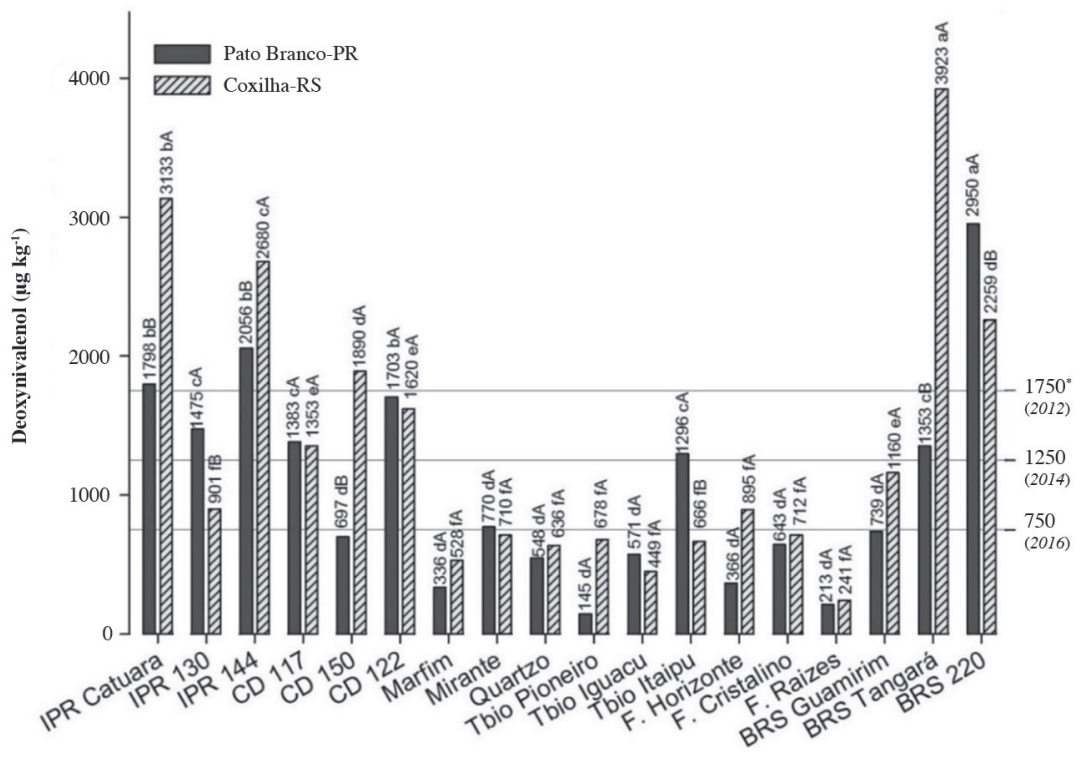

*Limits established by Brazilian Agency of Sanitary Surveillance (ANVISA) to the years 2012, 2014, and 2016, respectively.

Figure 4. Mean comparison of deoxynivalenol (DON) levels in samples of wheat flour of 18 cultivars grown in two representative locations of south Brazil, Pato Branco (Paraná) and Coxilha (Rio Grande do Sul), by the Scott Knott test at 5\% probability of error. Uppercase letters indicate significant differences between locations for the same cultivar, while lower-case letters indicate significant differences between cultivars in a particular location. 
had DON levels above the limit determined by ANVISA for the year 2012; however the occurrence of the FHB epidemics were slight low in the year that the study was performed (SISALERT, 2011). Therefore, we suggest intensifying the investigations in this field of study until the Brazilian wheat reaches all requirements in the coming years to keep this toxin within permissible levels.

\section{CONCLUSIONS}

Only $17 \%$ of the wheat flour samples were classified as inappropriate for consumption and $44 \%$ of the samples showed values already close to the limits established by the Brazilian Health Surveillance Agency up to the year 2016.

These preliminary results indicate that some of the tested varieties have potential to be exploited as a breeding source for low DON accumulation.

For the first time, variability of response of Brazilian wheat varieties to contamination by deoxynivalenol has been identified and some genotypes presented a reasonable lower level of DON accumulation.

\section{LITERATURE CITED}

Agostinelli, A.A., A.J. Clark, G.B. Guedira, and D.A.V. Sanford. 2012. Optimizing phenotypic and genotypic selection for Fusarium head blight resistance in wheat. Euphytica 186:115-126. ANVISA. 2011. Resolução RDC N ${ }^{\circ}$ 7, de 18 de fevereiro de 2011. Dispõe sobre limites máximos tolerados (LMT) para micotoxinas em alimentos. Diário Oficial da União (accessed February 2011). Agência Nacional de Vigilância Sanitária (ANVISA), Ministério da Saúde, Brasília-DF, Brasil.

Blandino, M., M. Haidukowski, M. Pascale, L. Plizzari, D. Scudellari, and A. Reyneri. 2012. Integrated strategies for the control of Fusarium head blight and deoxynivalenol contamination in winter wheat. Field Crops Research 133:139-149.

Bonin, C.M., and F.L. Kolb. 2009. Resistance to Fusarium head blight and kernel damage in a winter wheat recombinant inbred line population. Crop Science 49:1304-1312.

Calori-Domingues, M.A., R.R. Almeida, M.M. Tomiwaka, C.R. Gallo, E.M. Gloria, e C.T.S. Dias. 2007. Ocorrência de desoxinivalenol em trigo nacional e importado utilizado no Brasil. Ciência e Tecnologia de Alimentos 27:181-185.

Casa, R.T., E.M. Reis, M.M.C. Blum, A. Bogo, O. Scheer, e T. Zanata. 2004. Danos causados pela infecção de Gibberella zeae em trigo. Fitopatologia Brasileira 29:289-293.

Codex Alimentarius Commission. 2012. Proposed draft maximum levels for deoxynivalenol (DON) in cereals and cereal-based products and associated sampling plans including the possible revision of the code of practice for the prevention and reduction of mycotoxin contamination in cereals. Joint FAO/WHO Food Standards Programme, Codex Alimentarius Commission, 35th Session Rome, Italy. 2-7 July 2012. Codex Alimentarius Commission, Rome, Italy.

CONAB. 2013. Acompanhamento de safra brasileira de trigo. Companhia Nacional de Abastecimento, Brasília, Brasil. Available at http://www.conab.gov.br/ (accessed October 2013).
Cruz, C.D. 2013. Programa Genes: a software package for analysis in experimental statistics. Acta Scientiarum. Agronomy 35:271276.

Cui, L., J.N. Selvaraj, F. Xing, Y. Zhao, L. Zhou, and Y. Liu. 2013. A minor survey of deoxynivalenol in Fusarium infected wheat from Yangtze e Huaihe river basin region in China. Food Control 30:469-473.

Del Ponte, E.M., J.M.C. Fernandes, C.R. Pierobom, e G.C. Bergstrom. 2004. Giberela do trigo - aspectos epidemiológicos e modelos de previsão. Fitopatologia Brasileira 29:587-605.

Del Ponte, E.M., J. Garda-Buffon, and E. Badiale-Furlong. 2012. Deoxynivalenol and nivalenol in commercial wheat grain related to Fusarium head blight epidemics in southern Brazil. Food Chemistry 132:1087-1091.

Hallen-Adams, H.E., N. Wenner, G.A. Kuldau, and F. Trail 2011. Deoxynivalenol biosynthesis-related gene expression during wheat kernel colonization by Fusarium graminearum. Phytopathology 101:1091-1096.

Maul, R., C. Müller, S. Riess, M. Koch, F.J. Methner, and N. Irene. 2012. Germination induces the glucosylation of the Fusarium mycotoxin deoxynivalenol in various grains. Food Chemistry 131:274-279.

Miller, J.D., and P.G. Arnison. 1986. Degradation of deoxynivalenol by suspension cultures of fusarium head blight resistant wheat cultivar Frontana. Canadian Journal of Plant Pathology 8:147-159.

Mishra, S., K.M. Ansari, P.D. Dwivedi, H.P. Pandey, and M. Das. 2013. Occurrence of deoxynivalenol in cereals and exposure risk assessment in Indian population. Food Control 30:549-555.

Moazami, E.F., and S. Jinap. 2009. Natural occurrence of deoxynivalenol (DON) in wheat based noodles consumed in Malaysia. Microchemical Journal 93:25-28.

Ndossi, D.G., C. Frizzell, N.H. Tremoen, C.K. Faeste, S. Verhaegen, E. Dahl, et al. 2012. An in vitro investigation of endocrine disrupting effects of trichothecenes deoxynivalenol (DON), T-2 and HT-2 toxins. Toxicology Letters 214:268-278.

Rutkoski, J., J. Benson, Y. Jia, G.B. Guedira, J.L. Jannink, and M. Sorrells. 2012. Evaluation of genomic prediction methods for Fusarium head blight resistance in wheat. The Plant Genome 5:50-61

Samar, M.M., C.F. Fontán, S.L. Resnik, A.M. Pacin, and M.D. Castillo. 2003. Distribution of deoxynivalenol in wheat, wheat flour, bran, and gluten, and variability associated with the test procedure. Journal of AOAC International 86:551-556.

Santos, J.S., T.M. Souza, E.Y.S. Ono, E. Hashimoto, M.C. Bassoi, M.Z. Miranda, et al. 2013. Natural occurrence of deoxynivalenol in wheat from Paraná State, Brazil and estimated daily intake by wheat products. Food Chemistry 138:90-95.

Shephard, G.S. 2011. Fusarium mycotoxins and human health: a review. Plant Breeding and Seeds Science 64:113-121.

SISALERT. 2011. Sistema de alerta. Passo Fundo, Brasil. Available at http://mosaico.upf.br/ portal/?page_id=119 (accessed January 2011).

Stanković, S., J. Lević, D. Ivanović, V. Krnjaja, G. Stanković, and S. Tancić. 2012. Fumonisin B1 and its co-occurrence with other fusariotoxins in naturally contaminated wheat grain. Food Control 23:384-388.

West, J.S., S. Holdgate, J.A. Townsend, S.G. Edwards, P. Jennings, and B.D.L. Fitt. 2012. Impacts of changing climate and agronomic factors on fusarium ear blight of wheat in the UK. Fungal Ecology 5:53-61.

Zadoks, J.C., T.T. Chang, and C.F. Konzac. 1974. A decimal code for the growth stages of cereals. Weed Research 14:415-421. 